九州大学学術情報リポジトリ

Kyushu University Institutional Repository

Effects of nutritional level and carcase weight on the different anatomical body parts and muscle weights of male broilers

Roy, Bimol Chandra

Graduate School of Bioresource and Bioenvironmental Sciences, Kyushu University

Oshima, Ichiro

Graduate School of Bioresource and Bioenvironmental Sciences, Kyushu University

Miyachi, Hideyuki

Yokoo \& Co.

Nishimura, Shotaro

Faculty of Agriculture, Kyushu University

他

https://doi.org/10.5109/9279

出版情報: 九州大学大学院農学研究院紀要. 52 (1)，pp.43-48，2007-02-28. Faculty of Agriculture， Kyushu University

バージョン :

権利関係 : 


\title{
Effects of nutritional level and carcase weight on the different anatomical body parts and muscle weights of male broilers
}

\author{
Bimol Chandra ROY ${ }^{1}$, Ichiro OSHIMA ${ }^{1}$, Hideyuki MIYACHI ${ }^{2}$, Shotaro NISHIMURA, \\ Shoji TABATA and Hisao IWAMOTO*
}

\author{
Laboratory of Functional Anatomy, Division of Animal Science, Department of Animal and \\ Marine Bioresource Sciences, Faculty of Agriculture, Kyushu University, \\ Fukuoka 812-8581, Japan \\ (Received November 10, 2006 and accepted December 1, 2006)
}

1. The anatomical constituent of the carcase and the relative distribution of skeletal muscle in the different body parts were compared among male broiler groups reared with broiler foods with high nutritional levels for up to $80 \mathrm{~d}$ (H80d), and layer foods with low nutritional levels for up to 80 (L80d), 95 (L95d) and $108 \mathrm{~d}$ (L108d).

2. The carcase weight of the low nutrition birds increased from $2470 \mathrm{~g}$ in L80d to $3600 \mathrm{~g}$ in L108d through $2820 \mathrm{~g}$ in L95d, while H80d birds arrived at $2970 \mathrm{~g}$ after a $15 \mathrm{~d}$ shorter term of fattening compared to L95d. At that stage the carcase of H80d contained $49.2 \%$ whole skeletal muscle, similar to $50.9 \%$ in L108d, and these values were larger than the $45.8 \%$ in L80d and 44.8\% in L95d. Conversely, the whole visceral organ was contained at a smaller percentage in H80d and L108d compared to L80d and L95d. The percentage weight of whole bone, intermuscular adipose tissue, skin and abdominal fat did not differ among the bird groups, except for the L108d carcase which contained the smallest percentage whole bone.

3. The forelimbs muscles comprised $25.2 \%$ of the carcase in H80d and L108d, which was larger than 22.5-22.7\% in L80d and L95d. The muscle percentage of the hind limbs was largest in L108d (21.1\%), medium in H80d (19.4\%), and smallest in L80d (18.7\%) and L95d (18.0\%). The antebrachial muscle showed the largest percentage in H80d and the percentages of femoral and crural muscle were largest in L108d. The big shoulder muscle subpart was 20.2-20.3\% in H80d and L108d, which was larger than 17.9-18.0\% in L80d and L95d.

4. Age-related change of the percentage weight was observed markedly in the pectoralis, iliotibialis lateralis, flexor cruris lateralis and gastrocnemius muscles across the low nutrition bird groups with different ages. On the other hand, the H80d birds attained the largest percentage in the pectoralis, supracoracoideus, and femorotibiales muscles.

5. From these results, it was indicated that broiler foods with high nutritional levels do not only promote the growth rate of broiler, but also enhance the meat quality by stimulating the development of skeletal muscle within the valuable breast part.

\section{INTRODUCTION}

In domestic chickens, a diet with a high energy content promotes the growth rate and improves the feed efficiency for meat production (Farrell et al., 1976; Waldroup, 1981; Jackson et al., 1982; Sohn and Han, 1983a, b; Bartov, 1992; Leeson et al., 1996), but also is accompanied by the negative consequence of abundant deposition of abdominal fat (Griffin, 1996). Furthermore, it is reported that the carcase fatness does not change as long as the calorie to protein ratio in the diet remains constant (Bartov et al., 1974; Skinner et al., 1992). In pigs, the most important aspect of meat traits, fatness, is affected by several factors such as breed, diet, and muscle type (different myofibre types) (Wood et al., 2004).

The yield of white breast meat decreases more than that of dark meat when the body weight gain is reduced

\footnotetext{
${ }^{1}$ Laboratory of Functional Anatomy, Division of Animal Science, Department of Animal and Marine Bioresource Sciences, Graduate School of Bioresource and Bioenvironmental Sciences, Kyushu University

2 Yokoo \& Co, Ltd, Tosu-shi, 841-8602, Japan

* Corresponding author (E-mail: hiwamoto@agr.kyushu-u.ac.jp)
}

(Gordon and Charles, 2002). Slow growing genotypic chickens show a lower ratio of white to dark meat than conventional broilers, and are selected to produce dark meat rather than white (Fanatico et al., 2005).

Demands for high quality and further processed convenient meats which are sold as ready to cook in supermarkets have driven the poultry industry to change its marketing practices (Watts and Kennett, 1995; Roenigk and Pederson, 1987; Young et al., 2001). Where the various blocks of chicken are sold separately, the breast may attract a different price and is more valuable than the remainder blocks in numerous markets (Gous et al., 1999). Relative meat yield in the different parts could be altered by several factors such as strain, sex, age, health, nutrition, live weight, duration of feed withdrawal before processing and carcase down grading (McNally and Spicknall, 1949; Schmidt et al., 1964; Bouwkamp et al., 1973; Moran, 1977; Siegel et al., 1984). The baseline information for the general yield pattern in modern broilers was deduced from the regression analysis of edible parts to body weight by Brake et al. (1993). More recently, using rabbits with diverse body weights at the same age, indicated that the rabbits of small body size yield 3\% greater carcase, $3 \%$ larger hind limbs in relative proportion, and 11\% larger hind 
limbs in the ratio of meat to bone compared with the animals of large body size (Gondret et al., 2005).

Although merchandising of parts and further processed poultry needs yield information on various parts and components, in chicken only little information on the growth patterns of anatomically defined muscles is available. In the present study, the anatomical constituent of the carcase and the relative distribution of skeletal muscles among the different parts were examined using male broilers reared with broiler foods with a high nutritional level for up to $80 \mathrm{~d}$ (H80d), and layer foods with a low nutritional level for up to 80 (L80d, same age as H80d), 95 (L95d, same body weight as H80d), and 108 d (L108d, same percentage of whole muscle to carcase weight as H80d).

\section{MATERIALS AND METHODS}

\section{Birds and Foods}

Red Cornish× New Hampshire (RN, Shaver, Fort Medoc, France) cockerels were used after being reared with broiler diets with a high nutritional level for up to $80 \mathrm{~d}$ (H80d), and layer foods with a low nutritional level for up to 80 (L80d), 95 (L95d), and 108 d (L108d). The chemical composition of those foods is shown in Table 1 , of which the starters were fed for the first period of $21 \mathrm{~d}$ after hatching and thereafter the finishers. Throughout the experimental period, the cockerels were kept within a pen house and had ad libitum access to foods and water.

Sixteen birds of H80d, 16 birds of L80d, 8 birds of L95d and 8 birds of L108d were killed by a conventional neck cut to sever the carotid artery and jugular vein, bled completely and scalded at $60{ }^{\circ} \mathrm{C}$ for 2 min for plucking the feather and down by hand. The carcases were subsequently chilled in ice-water for more than $1 \mathrm{hr}$, and weighed after cutting off the head at atlanto-occipital joint and feet at intertarsal joint.

\section{Total skeletal muscle, bone, intermuscular adipose tissue, visceral organs, skin and abdominal fat}

After removing the skin, the skinned carcase was dissected into the body stem with visceral organs and abdominal fat, forelimbs and hind limbs parts. The total weight of skin, and those of the visceral organs and abdominal fat separated from the body stem part were measured. The total weight of intermuscular adipose tissue was measured as the combined value of the difference between the weights in each part before and after cleaning out the surface and intermuscular fatty tissue. The total skeletal muscle weight was the combined data of the weights in the parts, and also the total weight of bone (containing ligaments and tendons) was assessed from the weights in the parts measured after taking out every muscle.

\section{Measurement of muscle weights in groups, sub- groups and individual muscles}

When the carcase was divided into the parts and subparts, the muscle weight in each subpart was measured on the left side, and the weight in each part was calculated as the combined weight of those in the subparts. The carcase was divided into the body stem, forelimbs and hind limbs parts, and the body stem into dorsocaudal subpart (group of dorsal and caudal muscles, and obturatorius medialis muscle) and neck subpart (group of cervical muscles), the forelimbs part into an abdominal subpart (group of 4 abdominal muscles), shoulder subpart (the largest subpart composed of the muscle group over the shoulder girdle framework), brachial subpart (group of muscles with the belly on the brachial bone) and antebrachial subpart (group of muscles in the forearm and hand), and the hind limbs part into pelvic subpart (group of muscles connecting pelvic girdle and the proximal region of femoral bone except for obturatorius medialis), thigh subpart (group of muscles with the belly on the femoral bone), and crural subpart (group of muscles with the belly on the tarsotibial bone). The weights of the pectoralis, supracoracoideus, triceps brachii, iliotrochanterici, iliotibialis cranialis, iliotibialis lateralis, femorotibiales, flexor cruris lateralis, puboischiofemorales (medial and lateral heads), and gastrocnemius muscles were measured on the right side of the carcase.

\section{Statistical analysis}

All of the anatomical components and muscle weights were converted into percentage of carcase weight, and were available for comparing the bird groups with different body size. Means and the standard errors were calculated for the birds in each group and used for a $t$-test to find a significant difference between bird groups.

Table 1. Chemical composition of starter and finisher diets in the high and low nutritional group

\begin{tabular}{lcccccc}
\hline \multirow{2}{*}{ Composition } & \multicolumn{2}{c}{ High Nutritional Level } & & \multicolumn{2}{c}{ Low Nutritional Level } \\
\cline { 2 - 3 } \cline { 5 - 6 } & Starter & Finisher & & & Starter & Finisher \\
\hline Crude protein, $(\mathrm{g} / \mathrm{kg})$ & 205 & 161 & & & 177 & 142 \\
Ether Extract, $(\mathrm{g} / \mathrm{kg})$ & 40.0 & 44.1 & & & 11.0 & 41.4 \\
Crude Fibre, $(\mathrm{g} / \mathrm{kg})$ & 50.0 & 52.1 & & & 63.5 & 50.3 \\
Ash $(\mathrm{g} / \mathrm{kg})$ & 80.0 & 75.1 & & & 84.0 & 58.0 \\
Calcium $(\mathrm{g} / \mathrm{kg})$ & 8.00 & 5.70 & & & 4.15 & 3.80 \\
Phosphorus (g/kg) & 5.0 & 5.6 & & & 2.8 & 5.4 \\
Metabolisable energy (MJ /kg DM) & 13.2 & 11.9 & & & 11.6 & 11.7 \\
\hline
\end{tabular}




\section{RESULTS}

\section{Carcase weight}

The birds (H80d) reared on the diets with a high nutritional level showed a rapid growth rate, and consequently gained the greater carcase weight compared with the birds (L80d) fed on low nutritional food (Table 2). The birds (L95d) reared with the low nutritional foods took another 15 days or more to reach the same carcase weight as H80d. The L108d birds had another $780 \mathrm{~g}$ addition to the carcase weight as a result of $13 \mathrm{~d}$ more fattening compared to the L95d birds, and showed the largest weight of all bird groups.

Total skeletal muscle, bone, intermuscular adipose tissue, visceral organs, skin and abdominal fat

The percentage weights of whole skeletal muscle to carcase weight was significantly larger in H80d birds by $3.4 \%$ from that in L80d, and $4.4 \%$ from that in L95d; however, it did not differ between H80d and L108d birds (Table 2). Although the carcase weight of L95d birds reached to the same weight as that of H80d, the percentage weight of the skeletal muscle had not improved by the $15 \mathrm{~d}$ elongation of the fattening term. After another $13 \mathrm{~d}$ elongation of the term, the muscle percentage in L108d arrived at exactly the same value to that in H80d. Conversely the percentage weight of the whole bone and visceral weights in L108d decreased after growth from $80 \mathrm{~d}$ to $108 \mathrm{~d}$. The percentage weight of visceral organs was significantly smaller in L108d and H80d than L80d and L95d. The percentage weight of the whole bone was significantly smaller in L108d than L80d and H80d. The percentage weights of the intermuscular fatty tissue, skin and abdominal fat did not differ among the bird groups.

\section{Muscle weights in groups, subgroups and individ- ual muscles}

Group: In this chicken type, the largest forelimbs part containing half the whole skeletal muscle volume was most susceptible to the change in nutritional level of foods (Table 3). The H80d birds had the percentage

Table 2. Carcase weight and its compositional percentages of total muscle, bone, intermuscular adipose tissue, visceral, skin and abdominal fat

\begin{tabular}{|c|c|c|c|c|}
\hline Experimental groups & H80d & L80d & L95d & L108d \\
\hline No. of birds & 16 & 16 & 8 & 8 \\
\hline Carcase weight (g) & $2970 \pm 58 b$ & $2470 \pm 111 \mathrm{c}$ & $2820 \pm 82 b$ & $3600 \pm 164 \mathrm{a}$ \\
\hline Total muscle weight & $49.2 \pm 0.6 \mathrm{a}$ & $45.8 \pm 0.9 b$ & $44.8 \pm 0.9 b$ & $50.9 \pm 0.7 \mathrm{a}$ \\
\hline Total bone weight & $15.1 \pm 0.3 \mathrm{a}$ & $15.4 \pm 0.5 \mathrm{a}$ & $14.3 \pm 0.4 \mathrm{ab}$ & $13.5 \pm 0.7 \mathrm{~b}$ \\
\hline Total intermuscular adipose tissue weight & $3.1 \pm 0.2 \mathrm{a}$ & $3.2 \pm 0.2 \mathrm{a}$ & $3.6 \pm 0.3 \mathrm{a}$ & $3.3 \pm 0.3 \mathrm{a}$ \\
\hline Visceral weight & $15.6 \pm 0.5 b$ & $18.5 \pm 0.7 \mathrm{a}$ & $19.4 \pm 0.7 \mathrm{a}$ & $14.6 \pm 0.4 b$ \\
\hline Skin weight & $11.4 \pm 0.3 \mathrm{a}$ & $11.5 \pm 0.4 \mathrm{a}$ & $11.6 \pm 0.7 \mathrm{a}$ & $11.5 \pm 0.3 \mathrm{a}$ \\
\hline Abdominal fat weight & $3.2 \pm 0.3 \mathrm{a}$ & $3.1 \pm 0.3 \mathrm{a}$ & $3.3 \pm 0.7 \mathrm{a}$ & $3.3 \pm 0.4 \mathrm{a}$ \\
\hline
\end{tabular}

Means \pm standard errors

H80d; High nutritional chicken group at 80 days of age

L80d, L95d, L108d; Low nutritional chicken group at 80, 95 and 108 days of age, respectively

a, b, c The means with same letter do not differ significantly between chicken groups at $5 \%$ level

Table 3. The percentage weight of muscle group to carcase weight in the body parts and subparts

\begin{tabular}{ccccc}
\hline Experimental groups & H80d & L80d & L95d & L108d \\
\hline Forelimbs part & & & & \\
Shoulder subpart & $20.31 \pm 0.40 \mathrm{a}$ & $17.89 \pm 0.44 \mathrm{~b}$ & $17.99 \pm 0.37 \mathrm{~b}$ & $20.20 \pm 0.58 \mathrm{a}$ \\
Brachial subpart & $2.13 \pm 0.03 \mathrm{a}$ & $2.08 \pm 0.06 \mathrm{ab}$ & $1.95 \pm 0.03 \mathrm{~b}$ & $2.16 \pm 0.05 \mathrm{a}$ \\
Antebrachial subpart & $1.83 \pm 0.03 \mathrm{a}$ & $1.77 \pm 0.06 \mathrm{~b}$ & $1.60 \pm 0.03 \mathrm{c}$ & $1.67 \pm 0.05 \mathrm{bc}$ \\
Abdominal subpart & $0.97 \pm 0.02 \mathrm{a}$ & $1.01 \pm 0.03 \mathrm{a}$ & $0.99 \pm 0.05 \mathrm{a}$ & $1.13 \pm 0.04 \mathrm{a}$ \\
Combined & $25.24 \pm 0.40 \mathrm{a}$ & $22.75 \pm 0.54 \mathrm{~b}$ & $22.53 \pm 0.38 \mathrm{~b}$ & $25.16 \pm 0.60 \mathrm{a}$ \\
Hind limbs part & & & & \\
Pelvic subpart & $1.85 \pm 0.03 \mathrm{ab}$ & $1.79 \pm 0.05 \mathrm{~b}$ & $1.66 \pm 0.07 \mathrm{c}$ & $1.93 \pm 0.06 \mathrm{a}$ \\
Femoral subpart & $9.49 \pm 0.13 \mathrm{~b}$ & $8.99 \pm 0.21 \mathrm{bc}$ & $8.63 \pm 0.28 \mathrm{c}$ & $10.03 \pm 0.20 \mathrm{a}$ \\
Crural subpart & $8.01 \pm 0.30 \mathrm{a}$ & $7.93 \pm 0.15 \mathrm{a}$ & $7.72 \pm 0.25 \mathrm{a}$ & $9.16 \pm 0.19 \mathrm{a}$ \\
Combined & $19.35 \pm 0.25 \mathrm{~b}$ & $18.71 \pm 0.31 \mathrm{c}$ & $18.01 \pm 0.54 \mathrm{c}$ & $21.12 \pm 0.29 \mathrm{a}$ \\
Body stem part & & & & \\
Dorsocaudal subpart & $2.06 \pm 0.05 \mathrm{a}$ & $1.88 \pm 0.04 \mathrm{~b}$ & $1.92 \pm 0.05 \mathrm{ab}$ & $2.06 \pm 0.07 \mathrm{a}$ \\
Neck subpart & $2.57 \pm 0.06 \mathrm{a}$ & $2.47 \pm 0.08 \mathrm{ab}$ & $2.34 \pm 0.09 \mathrm{~b}$ & $2.57 \pm 0.11 \mathrm{a}$ \\
Combined & $4.63 \pm 0.11 \mathrm{a}$ & $4.35 \pm 0.11 \mathrm{~b}$ & $4.26 \pm 0.15 \mathrm{ab}$ & $4.63 \pm 0.15 \mathrm{ab}$ \\
\hline
\end{tabular}

Means \pm standard errors

H80d; High nutritional chicken group at 80 days of age

L80d, L95d, L108d; Low nutritional chicken group at 80, 95 and 108 days of age, respectively

$\mathrm{a}, \mathrm{b}, \mathrm{c}$ The means with same letter do not differ significantly between chicken groups at $5 \%$ level 
weight of the forelimbs muscle increase by $2.5-2.7 \%$ compared to those of L80d and L95d birds. After being reared for an additional $28 \mathrm{~d}$, the forelimbs muscle of the L108d birds arrived at the same percentage as in H80d. On the other hand, in the hind limbs muscle the largest percentage was observed in L108d, the second largest in H80d, and the smallest in L80d and L95d. The body stem muscle was significantly larger in H80d than L80d.

Subgroup: The shoulder subpart occupying $80 \%$ of the forelimbs part produced the largest muscle block of all subparts (Table 3). The percentage of shoulder muscle to the carcase weight was larger in H80d birds by 2.3-2.4\% from those of L80d and L95d, but no significant difference of the percentage was observed between H80d and L108d. The percentage of the antebrachial muscle was largest in H80d, followed by L80d, and smallest in L95d. The L108d birds showed a medium value between L80d and L95d in the percentage of antebrachial muscle, but did not differ significantly from each of them. The percentage of brachial muscle was significantly larger in H80d and L108d than L95d. The abdominal muscle developed markedly in L108d showing the largest percentage. No significant difference among H80d, L80d and L95d was observed in the percentage of the abdominal subpart.

In the hind limbs part, each of the subparts in L108d was largest in percentage of carcase weight of all bird groups with one exception; the pelvic muscle showed no difference between L108d and H80d. Moreover the femoral muscle exhibited a significantly larger percentage in H80d than L95d, and the pelvic muscle was larger in L80d than L95d. The crural subpart showed a significant difference between H80d and L80d. In the body stem part, the H80d and L108d chickens obtained the largest weight percentage dorsocaudal and neck subparts of all, where in the former subpart they showed a significant difference from L80d and in the latter from L95d.

Individual muscle: The pectoralis muscle was biggest in L108d at $13.08 \%$ and H80d at $12.92 \%$ of the carcase weight, which were significantly larger compared with $10.79 \%$ in L80d and $11.15 \%$ in L95d. Additionally, the supracoracoideus was largest in L108d and H80d, where these two muscles belong into the breast meat (Table 4). The iliotrochanterici, iliotibialis lateralis, flexor cruris lateralis and gastrocnemius muscles developed well in the L108d birds. The iliotibialis lateralis, femorotibiales and gastrocnemius muscles were significantly larger in percentage weight in H80d than L80d and L95d birds, as well as the iliotrochanterici muscles in H80d compared to L95d. The percentage weight of triceps brachii muscle did not show a significant difference among the chicken groups, and those of the iliotibialis cranialis and flexor cruris lateralis muscles did not differ among H80d, L80d, and L95d.

\section{DISCUSSION}

While foods with different energy contents can not change the actual food consumption, birds on high energy diets take in more metabolizable energy (Brue and Latshaw, 1985). The high energy diet hastens the chick's growth, and increases yields of the carcase and abdominal fat (Holsheimer and Veerkamp, 1992; Lott et al., 1992; Lei and Van Beeh, 1997; Yalcin et al., 1998). The relative weight of abdominal fat shows a positive interrelation to dietary energy (Yalcin et al., 1998). High protein diets can also stimulate chick growth, but do not stimulate an accumulation of abdominal fat if the calorie to protein ratio remains constant (Bartov et al., 1974; Skinner et al., 1992; Aggrey, 2004). In the present study, the percentage weight of abdominal fat to carcase weight did not differ among the bird groups regardless of the marked difference of carcase weights. Also the percentage weight of intermuscular adipose tissue did not differ among the bird groups.

The gastrointestinal system diminishes its relative size with body growth, and contributes to production of a greater eviscerated yield (Hayse and Marion, 1973; Moran, 1977). The results of this study indicated that the percentage of visceral weight is affected by both nutritional levels of diet and body growth. The H80d birds fed on high nutritional food contained relatively

Table 4. The percentage weight of different muscles in the body parts

\begin{tabular}{lrrrr}
\hline \multicolumn{1}{c}{ Experimental groups } & H80d & L80d & L95d & L108d \\
\hline M. pectoralis & $12.92 \pm 0.26 \mathrm{a}$ & $10.79 \pm 0.30 \mathrm{~b}$ & $11.15 \pm 0.33 \mathrm{~b}$ & $13.08 \pm 0.04 \mathrm{a}$ \\
M. supracoracoideus & $4.01 \pm 0.08 \mathrm{a}$ & $3.53 \pm 0.10 \mathrm{~b}$ & $3.76 \pm 0.08 \mathrm{ab}$ & $4.01 \pm 0.12 \mathrm{a}$ \\
M. triceps brachii & $0.94 \pm 0.02 \mathrm{a}$ & $0.94 \pm 0.03 \mathrm{a}$ & $0.93 \pm 0.04 \mathrm{a}$ & $0.99 \pm 0.05 \mathrm{a}$ \\
Mm. iliotrochanterici & $1.26 \pm 0.02 \mathrm{~b}$ & $1.26 \pm 0.03 \mathrm{ab}$ & $1.13 \pm 0.06 \mathrm{c}$ & $1.36 \pm 0.04 \mathrm{a}$ \\
M. iliotibialis cranialis & $0.84 \pm 0.04 \mathrm{ab}$ & $0.76 \pm 0.02 \mathrm{~b}$ & $0.82 \pm 0.08 \mathrm{ab}$ & $0.83 \pm 0.02 \mathrm{a}$ \\
M. iliotibialis lateralis & $2.27 \pm 0.05 \mathrm{~b}$ & $2.13 \pm 0.05 \mathrm{c}$ & $2.03 \pm 0.07 \mathrm{c}$ & $2.55 \pm 0.10 \mathrm{a}$ \\
Mm. femorotibiales & $2.55 \pm 0.05 \mathrm{a}$ & $2.39 \pm 0.04 \mathrm{~b}$ & $2.31 \pm 0.08 \mathrm{~b}$ & $2.40 \pm 0.05 \mathrm{ab}$ \\
M. flexor cruris lateralis & $1.26 \pm 0.04 \mathrm{~b}$ & $1.18 \pm 0.04 \mathrm{~b}$ & $1.17 \pm 0.03 \mathrm{~b}$ & $1.45 \pm 0.05 \mathrm{a}$ \\
Mm. puboischiofemorales & $1.00 \pm 0.03 \mathrm{a}$ & $0.93 \pm 0.02 \mathrm{~b}$ & $0.96 \pm 0.04 \mathrm{ab}$ & $0.96 \pm 0.04 \mathrm{ab}$ \\
M. gastrocnemius & $3.27 \pm 0.06 \mathrm{~b}$ & $3.06 \pm 0.06 \mathrm{c}$ & $3.15 \pm 0.09 \mathrm{c}$ & $3.82 \pm 0.11 \mathrm{a}$ \\
\hline
\end{tabular}

Means \pm standard errors

H80d; High nutritional chicken group at 80 days of age

L80d, L95d, L108d; Low nutritional chicken group at 80, 95 and L108 days of age, respectively

a, b, c The means with same letter do not differ significantly between chicken groups at $5 \%$ level 
smaller visceral organs compared with L80d and L95d birds, fed on low nutritional food. The L108d birds which were oldest and had the biggest carcase weight, also showed a small visceral content. On the other hand, the percentage weight of whole bone gradually decreased with advancing of age, from H80d and L80d to L108d through L95d birds. The percentage of skin weight did not change during this broiler growth stage ranging between $11.4-11.6 \%$, which is similar to the $11.1 \%$ reported by Moran et al. (1970).

Chickens with heavy body weight produce a greater percentage breast meat per carcase weight (Frichknecht and Jull, 1946; Marks, 1995; Moran, 1995; Goliomytis et al., 2003). The percentage of breast meat increases rapidly in the early growth stage up to 47-49 d after hatching, and the maximum growth rate was evaluated at $24.4 \mathrm{~g} / \mathrm{d}$ by Goliomytis et al. (2003). In the present study, H80d chickens arrived at the highest percentage of forelimbs muscle during this short growth period, and the L108d birds with slow growth elongated the rearing term more $28 \mathrm{~d}$ to attain the same percentage. Between H80d and L108d, the percentage of carcase weight did not differ in the shoulder and brachial subparts. Otherwise, the H80d birds attained the largest percentage in the antebrachial subpart and the L108d in the abdominal subpart. The biggest pectoralis and the second biggest supracoracoideus muscles in the shoulder subpart were larger in H80d and L108d than L80d and L95d, but the triceps brachii muscle in the brachial subpart did not differ among the groups. These muscles are primarily composed of fast-twitch glycolytic myofibres, which show extremely rapid growth for 1 week after hatching, especially in the former two muscles (Ono et al., 1989, 1993).

Goliomytis et al. (2003) reported that the percentage of femoral (containing pelvic) and crural muscles increase from $10.6 \%$ to $14.9 \%$ and from $7.7 \%$ to $9.1 \%$ respectively in the meat-type cockerels during the growth period of $7 \mathrm{~d}$ to $154 \mathrm{~d}$. In the present study, using 80 d to 108 d cockerels, the femoral + pelvic muscle increase was $10.3-12.0 \%$ and the crural muscle increase 7.7-8.0\%. These data appear to be a little smaller compared with those reported by Goliomytis et al. (2003). The percentages could increase with increasing body mass, and change on a relative size of the forelimbs and hind limbs parts (Iwamoto et al., 1992, 1993a, b; Fletcher and Carpenter, 1993; Goliomytis et al., 2003). The L108d chicken, which attained to the largest body mass, showed the largest percentage of hind limbs muscle to carcase weight, and the largest percentage of the pelvic, femoral and crural subparts. The second largest percentage of hind limbs muscle was shown by H80d birds but smaller than the percentage in L108d, which differed from the results in the forelimbs. From these results it is suggested that the foods with high nutritional level promote more muscle development in the forelimbs than the hind limbs.

The hind limbs of L108d birds contained the largest muscles, such as the gastrocnemius, iliotibialis lateralis, flexor cruris lateralis and iliotrochanterici, of all chicken groups. As the big postacetabular part of the iliotibialis lateralis muscle and the flexor cruris occupy the caudolateral region of the thigh, and the gastrocnemius is a strong extensor of the tarsal joint, these muscles play an important role in generating the propulsive power for locomotion. The iliotrochanterici muscles function as a protractor muscle of the femur and entire hind limbs. On the other hand, the H80d birds showed the same percentages as L108d in the femorotibiales, puboischiofemorales and iliotibialis cranialis muscles. These muscles occupy the craniomedial side of the thigh and contain much slow-twitch myofibres for supporting gravity and maintaining posture, which are earlier-maturing than the fast-twitch muscles in the thigh (Suzuki et al., 1985; Iwamoto et al., 1993a, b; Ono et al., 1993). From these results it is suggested that the high nutrition contents of H80d bird's foods could especially stimulate the development of the myofibres, showing a marked increase during the early growth stage regardless of the composition of myofibre types in the forelimbs' pectoralis and supracoracoideus muscles and the hind limbs' femorotibiales, puboischiofemorales and iliotibialis cranialis muscles (Ono et al., 1989, 1993).

In conclusion, different nutritional levels of the food fed to chickens could change the anatomical composition of the carcase and the relative distribution of skeletal muscles in parts and subparts. Broiler foods with high nutritional level enhanced body growth of broilers, and especially stimulated the breast muscle development. On the other hand, diets with low nutritional levels appeared to enlarge the relative size of the hind limbs' muscles by retarding the development of the forelimbs'.

\section{REFERENCES}

AGGREY, S. E. (2004) Modelling the effect of nutritional status on pre-asymptotic and relative growth rates in a random-bred chicken population. Journal of Animal Breeding and Genetics, 121: 260-268

BARTOV, I., BOMSTEIN, S. \& LIPSTEIN, B. (1974) Effects of Calorie to protein ratio on the degree of fatness in broilers fed on practical diets. British Poultry Science, 15: 107-117

BARTOV, I. (1992) Effects of energy concentration and duration of feeding on the response of broiler chicks to growth promoters. British Poultry Science, 33: 1057-1068.

BOUWKAMP, E. L., BIGBEE, D. E. \& WABECK, C. J. (1973) Strain influences on broiler parts yield. Poultry Science, 52: 1517-1523

BRAKE, J., HAVENSTEIN, G. B., SCHEIDELER, S. E., FERKET, P. R. \& RIVES, D. V. (1993) Relationship of sex, age, and body weight to broiler carcass yield and offal production. Poultry Science, 72: 1137-1145

BRUE, R. N. \& LATSHAW, J. D. (1985) Energy utilization by the broiler chicken as affected by various fats and fat levels. Poultry Science, 64: 2119-2130

FANATICO, A. C., PILlaI, P. B., CAVITT, L. C., OWENS, C. M. \& EMMERT, J. L. (2005) Evaluation of slower growing broiler genotypes grown with and without outdoor access: growth performance and carcass yield. Poultry Science, 84: 1321-1327

FARRELL, D. J., HARAKER, J. B., GREIG, I. D. \& CUMMING, R. B. (1976) Effects of dietary energy concentration on production 
of broiler chickens. Australian Journal of Experimental Agriculture and Animal Husbandry, 16: 672-678

FLETCHER, D. L. \& CARPENTER, J. A. (1993) Breast meat and part yield from four retail brands of broiler chickens obtained in the northeast Georgia. Poultry Science, 72: 2347-2352

FRISCHKNECHT, C. O. \& JULL, M. A. (1946) Amount of breast meat and live and dressed grades in relation to body measurements in 12-wk-old purebred and crossbred chickens. Poultry Science, 25: 330-345

GOLIOMYTIS, M., PANOPOULOU, E. \& ROGDAKIS, E. (2003) Growth curves for body weight and major component parts, feed consumption, and mortality of male broiler chickens raised to maturity. Poultry Science, 82: 1061-1068

GONDRET, F., LARZUL, C., COMBES, S. \& ROCHAMBEAU, H. DE. (2005) Carcass composition, bone mechanical properties, and meat quality traits in relation to growth rate in rabbits. Journal of Animal Science, 83: 1526-1535

GORDON, S. H. \& CHARLES, D. R. (2002) Niche and organic chicken products. Nottingham university press, Nottingham, UK

GOUS, R. M., MORAN Jr, E. T., STILBORN, H. R., BRADFORD, G. D. \& EMMANS, G. C. (1999) Evaluation of the parameters needed to describe the overall growth, the chemical growth and the growth of feathers and breast muscles of broilers. Poultry Science, 78: 812-821

GRIFFIN, H. D. (1996) Understanding genetic variation in fatness in chickens. Annual Report. Roslin Institute. Edinburg

HAYSE, P. L. \& MARION, W. W. (1973) Eviscerated yield, component parts, and meat, skin and bone ratios in the chicken broiler. Poultry Science, 52: 718-722

HOLSHEIMER, J. P. \& VEERKAMP, C. H. (1992) Effect of dietary energy, protein and lysine content on performance and yield of 2 strains of male broiler chicks. Poultry Science, 71: $872-879$

IWAMOTO, H., HARA, Y., ONO, Y. \& TAKAHARA, H. (1992) Breed differences in the histochemical properties of the $M$. iliotibialis lateralis myofibre of domestic cocks. British Poultry Science, 33: 321-328

IWAMOTO, H., HARA, Y., ONO, Y. \& TAKAHARA, H. (1993a) Breed differences in the histochemical properties of the $M$. pubo-ischio-femoralis pars medialis myofibre of domestic cocks. British Poultry Science, 34: 309-322

IWAMOTO, H., HARA, Y., GOTOH, T., ONO, Y. \& TAKAHARA, H. (1993b) Different growth rates of male chicken skeletal muscles related to their histochemical properties. British Poultry Science, 34: 925-938

JACKSON, S., SUMMERS, J. D. \& LEESON, S. (1982) Effect of dietary protein and energy on broiler carcass composition and efficiency of nutrient utilization. Poultry Science, 61: 2224-2231

LEESON, S., CASTON, L. \& SUMMERS, J. D. (1996) Broiler responses to energy or energy and protein dilution in the finisher diet. Poultry Science, 75: 522-528

LEI, S. \& VAN BEEH, G. (1997) Influence of activity and dietary energy on broiler performance, carcass yield and sensory quality. British Poultry Science, 38: 183-189

LOTT, B. D., DAY, E. J., DEATON, J. W. \& MAY, J. D. (1992) The effect of temperature, dietary energy level and corn particle size on broiler performance. Poultry science, $\mathbf{7 1}$ : 618-624

MARKS, H. L. (1995) Genetics of growth and development. World Animal Science, Poultry Production. P. Hunton, ed. Elsevier, Amsterdam, pp. 170-182

McNALLY, E, H. \& SPICKNALL, N. H. (1949) Meat yield from live, dressed, and eviscerated Rhode Island Red males of broiler, fryer, and light roaster weights. Poultry Science, $\mathbf{2 8}$ : 562-567

MORAN Jr, E. T., ORR, H. L. \& LARMOND, E. (1970) Dressing, grading and meat yields with broiler chicken breed. Food Technology, 24: 73-80

MORAN Jr, E. T. (1977) Growth and meat yield in poultry. Growth and Poultry Meat Production. K. N. Boorman and B. J. Wilson, ed. British Poultry Science, Ltd., Edinburgh, Scotland. pp. $145-173$

MORAN Jr, E. T. (1995) Body composition. World Animal Science, Poultry Production. P. Hunton, ed. Elsevier, Amsterdam. pp. 143-148

ONO, Y., IWAMOTO, H. \& TAKAHARA, H. (1989) Allometry of body weight, skeletal muscle weight and muscle fibre diameter in the chick. Japanese Journal of Zootechnical Science, 60: 958-964

ONO, Y., IWAMOTO, H., \& TAKAHARA, H. (1993) The relationship between muscle growth and the growth of different fibre types in the chicken. Poultry Science, 72: 568-576

ROENIGK, B. \& PEDERSEN, J. (1987) The dynamic broiler industry in 1990. Broiler Industry, 50 (1): 114, 116, 118, $120,122,124$

SCHMIDT, M. J., FORMICA, S. D. \& FRITZ, J. C. (1964) Effect of fasting prior to slaughter on yield of broilers. Poultry Science, 43: 931-934

SIEGEL, P. B., DUNNINGTON, E. A., JONES, D. E., UBOSI, C. O., GROSS, W. B. \& CHERRY, J. A. (1984) Phenotypic profiles of broiler stocks fed two levels of methionine and lysine. Poultry Science, 63: 855-862

SKINNER, J. T., WALDROUP, A. L. \& WALDROUP, P. W. (1992) Effects of dietary nutrient density on performance and carcass quality of broilers 42 to 49 days of age. Journal of Applied Poultry Research, 1: 367-372.

SOHN, K. S. \& HAN, I. K. (1983a) Studies on the protein and energy requirements of broiler chicks. I. The effects of varying dietary protein and energy levels on growth response of broiler chicks. Korean Journal of Animal Science, 25: 310-318

SOHN, K. S. \& HAN, I. K. (1983b) Studies on the protein and energy requirements of broiler chicks. II. The effects of varying dietary protein and energy levels on nutrient utilizability, content of the abdominal fat and the size of the internal organs. Korean Journal of Animal Science, 25: 319-324

SUZUKI, A., TSUCHIYA, T., OHWADA, S. \& TAMATE, H. (1985) Distribution of myofibre types in thigh muscles of chickens. Journal of Morphology, 185: 145-154

WALDROUP, P. W. (1981) Energy levels for broilers. Journal of American Oil Chemistry Society, 58: 309-313

WOOD, J. D., NUTE, G. R., RICHARDSON, R. I., WHITTINGTON, F. M., SOUTHWOOD, O., PLASTOW, G., MANSBRIDGE, R., COSTA, N. DA. \& CHANG, K. C. (2004) Effects of breed, diet and muscle on fat deposition and eating quality in pigs. Meat Science, 67: 651-667

WATTS, G. \& KENNETT, C. (1995) The Broiler Industry. Poultry Tribune (September): 6-18

YALCIN, A., OZKAN, S., ACIKGOZ, Z. \& OZKAN, K. (1998) Influence of dietary energy on bird performance, carcass parts yield and nutrient composition of breast meat of heterozygous Naked Neck broilers reared at natural optimum and summer temperatures. British Poultry Science, 39: 633-638

YOUNG, L. L., NORTHCUTT, J. K., BUHR, R. J., LYON, C. E. \& WARE, G. O. (2001) Effects of age, sex, and duration of postmortem aging on percentage yield of parts from broiler chicken carcasses. Poultry Science, 80: 376-379 